\section{SUMMARY}

1. The aerobic oxidation of ethyl and methyl gallates to ellagic acid in aqueous sodium bicarbonate solution, $\mathrm{pH} 7 \cdot 9$, and phosphate buffer, $\mathrm{pH} 8.0$, is reported. Autoxidation is incomplete, and mushroom polyphenoloxidase accelerates the initial uptake of oxygen in these media.

2. Enzymic oxidation in sodium bicarbonate solution gives a quantitative yield of ellagic acid, whereas in phosphate buffer a humic acid byproduct is also formed.

3. Ascorbic acid interrupts aerobic oxidations of methyl gallate in phosphate buffer, $\mathrm{pH} 7 \cdot 4$, whereas these oxidations are unaffected by ascorbic acid in sodium bicarbonate solution.

4. Aerobic oxidation of the tannin prototype, glucogallin, and of the gallotannin, chebulinic acid, gives ellagic acid.

5. Since ellagic acid most consistently occurs in those orders of the Dicotyledonse which contain gallates and gallotannins, the possibility that in some of these the gallate metabolites may behave as ellagic acid precursors is considered.

6. The fact that polyphenoloxidase is involved in the transformation of gallate into ellagate and in the polymerization through quinone of catechin into phlobatannin may be related to the simultaneous occurrence of ellagitannins and phlobatannins.

The author wishes to thank the Director and Council of the British Leather Manufacturers' Research Association for their permission to publish this paper. We are also indebted to Dr J. E. Page, of Glaxo Laboratories Ltd., Greenford, for the infrared spectra, and to Mr R. Lane for technical assistance.

\section{REFERENCES}

Bate-Smith, E. C. (1956). Chem. \& Ind. p. R32.

Bradfield, A. E. \& Flood, A. E. (1952). J. chem. Soc. p. 4740.

Campbell, P. N., Work, T. S. \& Mellanby, E. (1951). Biochem. J. 48, 106.
Carlson, H. J., Olynyk, P., Duncan, H. \& Smolin, A. (1951). Antibiot. \& Chemother. 1, 431.

Caughley, R. A., Holland, G. B. \& Ritchie, W. S. (1939). J. Ass. off. agric. Chem. Wash. $22,333$.

Fischer, E. \& Bergmann, M. (1918). Ber. dtsch. chem. Ges. $51,1760$.

Freudenberg, K. \& Frank, T. (1927). Liebigs Ann. 452, 303.

Fridolin, A. (1884a). Diss. Dorpat.

Fridolin, A. (1884b). S.B. Dorpat Naturforsch. Ges. 7, 131.

Fujikawa, F., Nakamura, I. \& Asami, K. (1942). J. pharm. Soc. Japan, 62, 343.

Gilson, E.(1903). Bull. Acad. Méd. Belg. [4], 16, 837, 842, 851.

Hathway, D. E. (1956a). Nature, Lond., 177, 747.

Hathway, D. E. (1956b). Biochem. J. 63, 380.

Hathway, D. E. (1956c). Symp. Soc. Leath. Tr. Chem., The Chemistry of Vegetable Tannins, p. 131.

Hathway, D. E. (1957). J. chem. Soc. p. 519.

Hathway, D. E. \& Seakins, J. W. T. (1955). Nature, Lond., 176, 218.

Hathway, D. E. \& Seakins, J. W. T. (1957a). Biochem. J. 65, $32 \mathrm{P}$.

Hathway, D. E. \& Seakins, J. W. T. (1957b). Biochem. J. 67, 239.

Herzig, J., Pollak, G. \& Bronneck, M. von (1908). Mh. Chem. 29, 263.

Huzii, K., Huzikawa, H. \& Kudo, Y. (1937). J. pharm. Soc. Japan, 57, 140.

Huzikawa, H. \& Ina, M. (1940). J.pharm. Soc. Japan, 60, 125.

James, T. H., Snell, J. M. \& Weissberger, A. (1938). J. Amer. chem. Soc. 60, 2084.

Kielin, D. \& Mann, T. (1938). Proc. Roy. Soc. B, 125, 187.

King, H. G. C. (1956). Chem. \& Ind. p. 658.

Mayer, W. (1956). Symp. Soc. Leath. Tr. Chem., The Chemistry of Vegetable Tannins, p. 127.

Nierenstein, M. (1905). Collegium, Haltingen, 162, 197.

Schmidt, O. T. (1956). Symp. Soc. Leath. Tr. Chem., The Chemistry of Vegetable Tannins, p. 67.

Schmidt, O. T. \& Mayer, W. (1956). Angew. Chem. 68, 103. Sosa, A. (1950). Bull. Soc. Chim. biol., Paris, $32,344$.

Stark, J. B., Goodban, A. E. \& Owens, H. S. (1951). Analyt. Chem. 23, 413.

Wehmer, C. \& Hadders, M. (1932). In Handbuch der Pflanzenanalyse, vol. 3, part 1, p. 407. Ed. by Klein, G. Wien: Springer-Verlag.

Willis, J. C. (1931). A Dictionary of the Flowering Plants and Ferns, 6th ed. Cambridge University Press.

\title{
The Biosynthesis of Sucrose
}

\author{
BY J. F. TURNER* \\ Botany School, University of Cambridge
}

(Received 17 April 1957)

Although sucrose is the most widespread and generally the most abundant sugar present in plants, the mechanism of sucrose synthesis by the plant has, until recently, remained obscure.

* Present address: Division of Food Preservation and Transport, C.S.I.R.O., Botany School, University of Sydney, Australia.
Numerous experiments have been carried out on the formation of sucrose in intact plant tissues when these were supplied with hexoses, e.g. Nelson \& Auchincloss (1933), Nurmia (1935), Leonard (1939). Calvin \& Benson (1949) allowed the alga Chlorella to photosynthesize in the presence of ${ }^{14} \mathrm{CO}_{2}$ and found that the first labelled frec carbohydrate to appear- 
was sucrose. Glucose and fructose were present, but were not radioactive, and it was concluded that these sugars were not intermediates in sucrose formation but that the probable intermediates were hexose phosphates. Buchanan et al. (1952), studying the photosynthesis of Scenedesmus with ${ }^{14} \mathrm{CO}_{2}$, confirmed that sucrose was the first radioactive free sugar to appear. Before sucrose was formed radioactivity appeared in hexose monophosphates and in uridine diphosphate glucose (UDPG), and it was suggested that sucrose synthesis in the plant may be by transfer of a glucosyl group from UDPG to a fructose phosphate to yield a sucrose phosphate.

Preliminary accounts of some of the experiments reported here have been published (Turner, 1953, 1954). It was found that an extract from dried pea seeds formed sucrose from a mixture of glucose 1-phosphate and fructose. Further experiments produced evidence consistent with the participation of UDPG in the synthesis but indicated that free fructose (and not a fructose phosphate) was a precursor. Since this work was carried out Leloir \& Cardini (1953) have reported the occurrence in plant tissues of an enzyme which catalyses the reaction

UDPG + fructose $\rightleftharpoons$ sucrose + uridine diphosphate.

It is probable that this reaction is the final step in sucrose formation from glucose 1-phosphate and fructose by pea extracts.

This paper describes the methods of preparation of the extracts of pea enzyme and gives details of the factors affecting sucrose formation and of the properties of a sample of synthetic sucrose. The possible relationship of these findings to sucrose synthesis in the plant is discussed.

\section{MA'TERIALS AND METHODS}

\section{Substrates}

Sugars. Commercial preparations of glucose, fructose and sucrose, which gave only one spot when examined on paper chromatograms with butanol-acetic acid-water (4:1:5, by vol.) as solvent, were used.

Phosphate esters. Glucose 1-phosphate was kindly supplied by Professor C. S. Hanes. Adenosine triphosphate (ATP) and diphosphopyridine nucleotide (DPN) were kindly supplied by the late Mr E. J. Morgan. Samples were later obtained from Pabst Laboratories (Milwaukee, Wis., U.S.A.).

A sample of synthetic uridine $5^{\prime}$-phosphate (UMP) was kindly supplied by Professor Sir Alexander Todd.

\section{Methods}

The preparation of the enzyme extracts is described in another section. The enzyme digests were carried out at $25^{\circ}$. Digest samples were inactivated by the addition of tri- chloroacetic acid, kept cool and manipulations carried out without delay; under these conditions there was no detectable hydrolysis of sucrose.

Estimation of phosphate. Inorganic orthophosphate was determined by this modification of the method of Allen (1940): The sample (not greater than $2 \mathrm{ml}$.) was placed in a colorimeter tube and the volume adjusted (if necessary) to $2 \mathrm{ml}$. by the addition of water. Mixed amidol reagent (5 ml.) was then added, the contents of the tube were mixed and the absorption was measured at $660 \mathrm{~m} \mu$ after $15 \mathrm{~min}$. The mixed amidol reagent was prepared immediately before use by taking $10 \mathrm{ml}$. of $\mathrm{HClO}_{4}(60 \%, w / v), 10 \mathrm{ml}$. of the amidolbisulphite reagent of Allen and $5 \mathrm{ml}$. of $8.3 \%(w / v)$ ammonium molybdate and diluting to $100 \mathrm{ml}$. with water.

Chromatography of sugars. Fructose and sucrose were the only simple sugars usually present in the enzyme digests studied. A single-phase mixture of propanol-water-aq. $\mathrm{NH}_{3}$ soln. (16:3:1, by vol.) was found to be suitable and was used for all quantitative work. The presence of ammonia produced more compact spots than propanol-water $(4: 1$, $\mathrm{v} / \mathrm{v}$ ) and had the advantage of neutralizing the extracts from enzymic digests which were applied to the chromatogram in trichloroacetic acid solution. Another advantage was that phosphoric esters of sugars remained on the 'starting line' and thus did not interfere with subsequent estimation of the sugars.

Spraying reagents. The sprays used included naphtharesorcinol- $\mathrm{H}_{3} \mathrm{PO}_{4}$ (Bryson \& Mitchell, 1951), benzidinetrichloroacetic acid (Bacon \& Edelman, 1951) and $\mathrm{AgNO}_{3}-$ $\mathrm{NaOH}$ (Trevelyan, Procter \& Harrison, 1950).

Estimation of sugars. Trichloroacetic acid extracts containing the sugars were applied to Whatman no. 3 paper chromatograms and developed with propanolwater-aq. $\mathrm{NH}_{3}$ soln. solvent. The area of paper containing the sugar to be estimated was cut out and soaked in water. The sugars in this aqueous extract were determined by the resorcinol method of Cole, Hanes, Jackson \& Loughman (1955).

Preparation of the crude extract. Pea seeds (var. Laxton's Progress) were finely ground in a Christie and Norris mill and the powder was extracted three times with ether at room temperature and air-dried. The defatted powder was stored at $4^{\circ}$ and showed no loss of sucrose-forming activity during a period of 6 months.

For the preparation of the enzyme extract, $15 \mathrm{~g}$. of defatted pea powder was suspended in a mixture of $40 \mathrm{ml}$. of glass-distilled water, $5 \mathrm{ml}$. of toluene and $10 \mathrm{ml}$. of $0.2 \mathrm{M}$ $\mathrm{NaHCO}_{8}$ in a stoppered bottle. The bottle was slowly rotated for $3 \mathrm{hr}$. at room temperature on a pair of mechanical rollers. The mixture was centrifuged at $1000 \mathrm{~g}$ for $10 \mathrm{~min}$. and the supernatant used for enzyme experiments. Studies of sucrose synthesis and the liberation of inorganic phosphate by this extract were reported previously (Turner, 1953).

Preparation of partially purified extracts from peas. Attempts to dialyse the crude pea extract against water, tap water and $1 \%(\mathrm{w} / \mathrm{v}) \mathrm{KCl}$ resulted in a complete loss of ability to synthesize sucrose. The activity was not restored by the addition of a boiled crude pea extract.

Dialysis against phosphate buffers for $20 \mathrm{hr}$. at $4^{\circ}$ caused complete loss of activity. It was found, however, that when the preparation was subjected to dialysis for only $5 \mathrm{hr}$. at $4^{\circ}$ against $0.025 \mathrm{M}$-phosphate buffer $\left(\mathrm{KH}_{2} \mathrm{PO}_{4}-\mathrm{NaOH}\right), \mathrm{pH} 7$, some activity remained. 


\section{RESULTS}

Effect of boiled pea extract and $\mathrm{Mg}^{2+}$ ions. It had been observed that fluoride inhibited sucrose synthesis by crude pea extracts and this suggested that $\mathrm{Mg}^{2+}$ ions might be essential for the reaction. Boiled pea extract was prepared by boiling the crude pea extract for $4 \mathrm{~min}$. and centrifuging at $20000 \mathrm{~g}$ for $15 \mathrm{~min}$. Both boiled extract and $\mathrm{MgCl}_{2}$ markedly stimulated sucrose synthesis by a pea extract which had been dialysed for $5 \mathrm{hr}$. against 25 mM-phosphate buffer.

To ascertain whether the stimulation given by the boiled pea extract was due to $\mathrm{Mg}^{2+}$ ions, a more rigorously dialysed preparation was made. The crude pea extract was placed in a dialysis sac which contained a thick glass rod. The sac was immersed in phosphate buffer (25 mM, pH 7) contained in a cylinder which was placed on a mechanical rocking machine. Slow rocking was continued for $5 \mathrm{hr}$. at $4^{\circ}$. It was found that the addition of boiled pea extract greatly increased sucrose synthesis above that given by the optimum concentration (10 mM) of $\mathrm{MgCl}_{2}$. It was therefore concluded that boiled pea extract contained a factor or factors, other than $\mathrm{Mg}^{2+}$ ions, essential for the synthesis of sucrose.

Precipitation by ammonium sulphate. The crude pea extract (prepared as described above) was centrifuged at $20000 \mathrm{~g}$ for $20 \mathrm{~min}$. at room temperature and the precipitate discarded. Centrifuging at high speed at this stage was necessary to secure satisfactory sedimentation after the addition of $\left(\mathrm{NH}_{4}\right)_{2} \mathrm{SO}_{4}$. Cold neutralized saturated $\left(\mathrm{NH}_{4}\right)_{2} \mathrm{SO}_{4}$ $(80 \mathrm{ml}$.) was added to $20 \mathrm{ml}$. of the turbid supernatant. After standing for $1 \mathrm{hr}$. at $4^{\circ}$ the mixture was centrifuged at $20000 \mathrm{~g}$ for $20 \mathrm{~min}$. at room

Table 1. Effect of nucleotide fractions and boiled pea extract on sucrose synthesis by the partially purified extract

The digest (total vol. $1.8 \mathrm{ml} ., \mathrm{pH} 7$ ) contained glucose 1-phosphate, $14.4 \mathrm{mM} ; \mathrm{MgCl}_{2}, 10 \mathrm{~mm}$; partially purified extract, $1 \mathrm{ml}$. Additions were fructose, $24 \cdot 4 \mathrm{mM}$; boiled pea extract, $0.5 \mathrm{ml}$; yeast-nucleotide fraction, $0.5 \mathrm{ml}$.; pea-nucleotide fraction, $0.5 \mathrm{ml}$.

Sucrose

\section{Additions}

None

Fructose

Boiled extract

Boiled extract plus fructose

Yeast nucleotide

Yeast nucleotide plus fructose

Pea nucleotide

Pea nucleotide plus fructose ( $\mu \mathrm{moles} / \mathrm{ml}$. of digest)

$\overbrace{\begin{array}{c}\text { After } \\ 41 \mathrm{hr} .\end{array}}^{(\mu \mathrm{moles} / \mathrm{ml} \text {. of digest) }} \begin{gathered}\begin{array}{c}\text { Difference due } \\ \text { to fructose } \\ \text { addition }\end{array} \\ \text { addition }\end{gathered}$

0

0

$6 \cdot 3$

$13 \cdot 5$

0

$5 \cdot 6$

0

$4 \cdot 8$

temperature. Good sedimentation was not obtained at lower speeds. The supernatant was discarded and the precipitate taken up in water $(7 \mathrm{ml})$. and dialysed on the rocking apparatus as described above. Dialysis was continued for $2 \mathrm{hr}$. at $4^{\circ}$ against $300 \mathrm{ml}$. of $25 \mathrm{~mm}$-phosphate buffer ( $\mathrm{pH} \mathrm{7}$ ), the phosphate buffer being renewed four times in this period. The final volume of the extract was approx. $12 \mathrm{ml}$. This procedure was used for most subsequent work and the preparation will be referred to as the 'partially purified extract'.

The short period of dialysis $(2 \mathrm{hr}$.) was found to be preferable to a longer period. Dialysis for 5-6 hr. sometimes gave inactive preparations. The $\left(\mathrm{NH}_{4}\right)_{2} \mathrm{SO}_{4}$ precipitate, when suspended in water and used without dialysis, was inactive. The preparation synthesized sucrose from glucose 1phosphate and fructose only in the presence of boiled extract (or equivalent cofactors) and $\mathbf{M g}^{2+}$ ions.

Replacement of boiled extract by nucleotide fractions prepared from yeast and peas. The hypothesis of Buchanan et al. (1952) that UDPG may be a precursor of sucrose in Scenedesmus led to attempts to replace the boiled crude pea extract by nucleotide fractions which would contain UDPG.

The initial steps of the method of Caputto, Leloir, Cardini \& Paladini (1950) for the preparation of UDPG from yeast were followed. The nucleotides of baker's yeast were extracted with hot ethanol and precipitated twice with mercuric acetate. The precipitate was decomposed with $\mathrm{H}_{2} \mathrm{~S}$ and filtered. This filtrate is termed the 'yeast-nucleotide fraction'. A similar fraction was prepared from defatted pea powder.

Both the yeast- and pea-nucleotide fractions stimulated sucrose synthesis by the partially purified enzyme system (Table 1). There was no formation of sucrose in the absence of the boiled pea extract or the nucleotide fractions.

\section{Studies on sucrose synthesis by the partially purified extract}

The formation of sucrose from glucose 1-phosphate and fructose by the partially purified extract was described earlier (Turner, 1954).

Effect of $\mathrm{Mg}^{2+}$ ion concentration on sucrose synthesis. The system was inactive in the absence of added $\mathrm{Mg}^{2+}$ ions and reached maximum activity at approximately $10 \mathrm{mM}-\mathrm{MgCl}_{2}$ (Fig. 1).

Effect of concentration of yeast-nucleotide fraction on sucrose synthesis. An interesting effect was observed when the concentration of the yeastnucleotide fraction was varied in the enzymic digests. With increasing concentration the rate of sucrose formation rose until an optimum was reached. Further increase of the yeast-nucleotide fraction considerably decreased the amount of 
sucrose formed (Fig. 2). Increase of the yeastnucleotide fraction accelerated the disappearance of fructose but a definite optimum concentration was not observed.

Effect of substrate concentration on sucrose synthesis. The effect on sucrose synthesis of varying the concentrations of glucose 1-phosphate and fructose is shown in Fig. 3. The initial concentrations of glucose 1-phosphate and fructose were equal, and this concentration was varied in each reaction mixture.

There was a marked optimum concentration of substrates at approx. $30 \mathrm{~mm}$ and further increase lowered the formation of sucrose. In a separate experiment in which the initial concentration of glucose 1-phosphate was $14.4 \mathrm{~mm}$ and fructose was

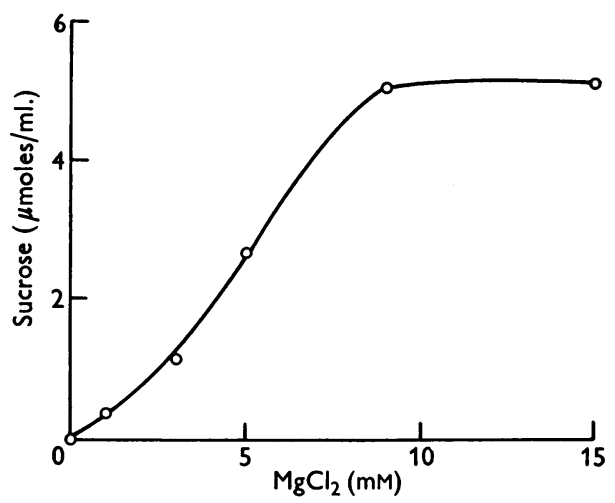

Fig. 1. Effect of $\mathrm{MgCl}_{2}$ concentration on sucrose formation. The digest (total vol. $1 \mathrm{ml} ., \mathrm{pH} \mathrm{7}$ ) contained glucose 1-phosphate, $13 \mathrm{~mm}$; fructose, $22 \mathrm{~mm}$; yeast-nucleotide fraction, $0.25 \mathrm{ml}$; partially purified extract, $0.5 \mathrm{ml}$. Incubation period, $17 \mathrm{hr}$.

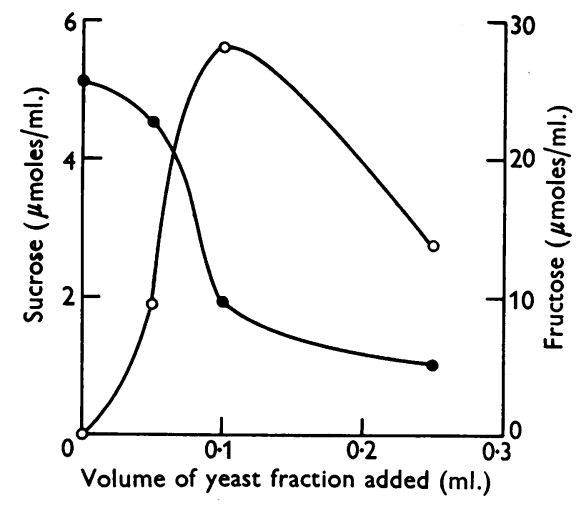

Fig. 2. Effect of addition of yeast-nucleotide fraction on sucrose formation and fructose loss. The digest (total vol. $0.9 \mathrm{ml}$., pH 7) contained glucose 1-phosphate, $14.4 \mathrm{~mm}$; fructose, $24.4 \mathrm{~mm}$; $\mathrm{MgCl}_{2}, 10 \mathrm{~mm}$; partially purified extract, $\mathbf{0 . 5} \mathrm{ml}$. Incubation period, $17 \mathrm{hr}$. O, Sucrose; , fructose. added to digests in concentrations from 27.5 to $110 \mathrm{~mm}$, there was no significant change in the amount of sucrose formed. The depressing effect of higher concentration of substrates on sucrose formation may therefore be due to the increase of glucose 1-phosphate rather than of fructose.

Effect of inhibitors on sucrose synthesis. The effects of several inhibitors on the formation of sucrose from glucose 1-phosphate and fructose by the partially purified extract are listed in Table 2. Both fluoride and iodoacetate completely inhibited sucrose formation.

Cofactor requirement for sucrose synthesis. The quantity of UDPG present in the yeast nucleotide fraction was insufficient to account for the sucrose synthesis in enzyme digests if it were assumed that the glucose moiety in the sucrose produced was provided by preformed UDPG. The yeast-nucleotide fraction was heated in $0.01 \mathrm{~N}-\mathrm{HCl}$ for $5 \mathrm{~min}$. at $100^{\circ}$, a treatment which splits the glucose from UDPG (Caputto. et al. 1950). Examination of the hydrolysed material on a paper chromatogram

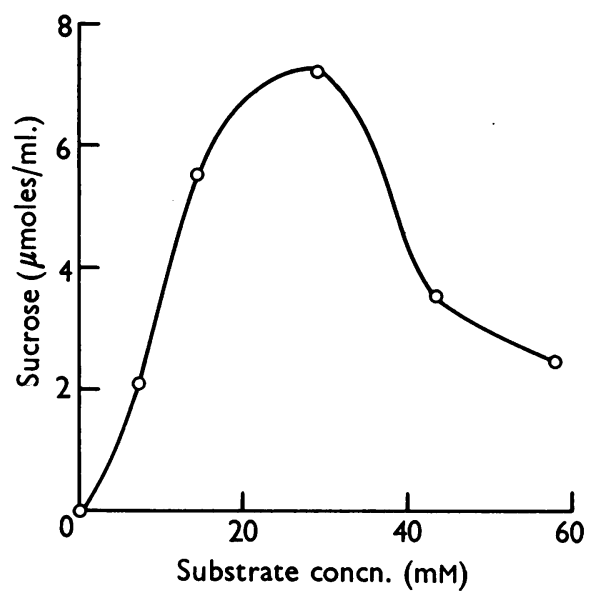

Fig. 3. Effect of substrate concentration on sucrose formation. The digest (total vol. $0.9 \mathrm{ml}$., pH 7) contained $\mathrm{MgCl}_{2}, 10 \mathrm{mM}$; yeast-nucleotide fraction, $0.1 \mathrm{ml}$; partially purified extract, $0.5 \mathrm{ml}$. Glucose 1-phosphate and fructose were added in the concentrations shown. Incubation period, $18 \mathrm{hr}$.

Table 2. Effects of inhibitors on sucrose synthesis

The digest (total vol. $0.9 \mathrm{ml} ., \mathrm{pH} 7$ ) contained glucose 1-phosphate, $14.4 \mathrm{~mm}$; fructose, $24.4 \mathrm{~mm}$; $\mathrm{MgCl}_{2}, 10 \mathrm{~mm}$; yeast-nucleotide fraction, $0.1 \mathrm{ml}$; partially purified extract, $0.5 \mathrm{ml}$. Time of incubation, $18 \mathrm{hr}$.

$\begin{array}{lcc}\text { Inhibitor } & \begin{array}{c}\text { Final concn. } \\ (\mathrm{mM})\end{array} & \begin{array}{c}\text { Inhibition } \\ (\%)\end{array} \\ \text { Iodoacetate } & 0 \cdot 1 & 100 \\ \text { Fluoride } & 6 \cdot 5 & 100 \\ \text { 2:4-Dinitrophenol } & 0 \cdot 1 & 0 \\ \text { 2:4-Dinitrophenol } & 1 & 27\end{array}$


showed only an extremely small amount of glucose. Hydrolysis in $\mathrm{N}-\mathrm{HCl}$ for $15 \mathrm{~min}$. at $100^{\circ}$ (UDPG contains one acid-labile phosphate group) produced only a trace of inorganic phosphate.

It was also observed that treatment of the yeastnucleotide fraction for $5 \mathrm{~min}$. at $100^{\circ}$ with $0.01 \mathrm{~N}$ $\mathrm{HCl}$ or with $0.01 \mathrm{~N}-\mathrm{NaOH}$ (conditions which lead to the destruction of UDPG, Caputto et al. 1950) failed to destroy the coenzyme activity of this fraction in the sucrose synthesis.

The formation of sucrose was therefore not dependent on the presence of UDPG as such in the yeast-nucleotide fraction.

Effects of diphosphopyridine nucleotide, adenosine triphosphate and uridine monophosphate. Consideration of the results of the experiments previously described indicated that a glycolytic system might have been operating in the enzymic digests during sucrose synthesis. The digests produced considerable amounts of $\mathrm{CO}_{2}$. A glycolytic system would require the presence of DPN as a cofactor.

The ability of the yeast-nucleotide fraction to promote sucrose synthesis was completely destroyed by heating for $10 \mathrm{~min}$. in $\mathrm{N}-\mathrm{HCl}$ at $100^{\circ}$. Heating with $0 \cdot 1 \mathrm{~N}-\mathrm{HCl}$ under the same conditions caused $70 \%$ destruction of the cofactor activity. Euler, Schlenk, Heiwinkel \& Högberg (1938) have shown that the oxidized form of DPN is approx. $63 \%$ destroyed in $10 \mathrm{~min}$. in $0.1 \mathrm{~N}-\mathrm{HCl}$ at $100^{\circ}$.

Preliminary experiments indicated that DPN was a cofactor in sucrose formation from glucose 1phosphate and fructose by the partially purified extract. If a glycolytic system were operating in digests synthesizing sucrose it would be expected that adenosine phosphates would be required. Accordingly, the effect of the addition of ATP was studied. UMP was also added.

UMP and ATP did not induce sucrose formation in the absence of DPN (Table 3). When DPN was present, both of these substances, especially UMP,

Table 3. Effects of diphosphopyridine nucleotide, uridine monophosphate and adenosine triphosphate on sucrose synthesis

The digest (total vol. $0.9 \mathrm{ml} ., \mathrm{pH} 7$ ) contained glucose 1-phosphate, 14.4 mM; fructose, $24.4 \mathrm{mM} ; \mathrm{MgCl}_{2}, 10 \mathrm{mM}$; partially purified extract, $0.5 \mathrm{ml}$. Additions were DPN, $0.2 \mathrm{mg}$; UMP, $64 \mu \mathrm{M}$; ATP, $34 \mu \mathrm{M}$. Time of incubation, $19 \mathrm{hr}$.

$\begin{array}{lc}\text { Additions } & \begin{array}{c}\text { Sucrose } \\ (\mu \mathrm{moles} / \mathrm{ml} . \text { of digest })\end{array} \\ \text { None } & 0 \\ \text { UMP } & 0 \\ \text { ATP } & 0 \\ \text { DPN } & \mathbf{3 \cdot 8} \\ \text { DPN + UMP } & \mathbf{5 \cdot 2} \\ \text { DPN + ATP } & \mathbf{4 \cdot 2} \\ \text { DPN + ATP + UMP } & \mathbf{5 \cdot 4}\end{array}$

gave greater sucrose synthesis than that given by DPN alone.

Some properties of a sample of synthetic sucrose. As neither the partially purified extract nor the yeast-nucleotide fraction contained sucrose it was possible to prepare a synthetic sample of this sugar.

A digest containing 14.4 mM-glucose 1-phosphate, $24 \cdot 4 \mathrm{~mm}$-fructose, $10 \mathrm{~mm}-\mathrm{MgCl}_{2}$, $1 \mathrm{ml}$. of yeastnucleotide fraction and $5 \mathrm{ml}$. of partially purified extract (total vol. $9 \mathrm{ml}$.) was incubated at $25^{\circ}$. After $40 \mathrm{hr}$. ethanol was added to give a final concentration of $75 \%$; the mixture was centrifuged and the supernatant evaporated to a small volume under reduced pressure. The extract was applied as 'streaks' to Whatman no. 3 papers which had been chromatographically washed with acetic acidaq. $\mathrm{NH}_{3}$ soln.-water. The chromatograms were developed for $40 \mathrm{hr}$. in butanol-ethanol-water (10:1:2, by vol.). The area containing sucrose was soaked in water and the extract taken to dryness in vacuo at $0^{\circ}$.

The synthetic sample and an authentic sample of sucrose were examined on paper chromatograms with the following four solvents: propanol-wateraq. $\mathrm{NH}_{3}$ soln. (16:3:1, by vol.), butanol-ethanolwater (10:1:2, by vol.), ethyl acetate-propanolwater $(57: 13: 32$, by vol.) and butanol-acetic acidwater (4:1:5, by vol.). Both the synthetic and authentic samples travelled identical distances in all four cases.

Synthetic sucrose was heated at $100^{\circ}$ for $4 \mathrm{~min}$. in $0.025 \mathrm{~N}-\mathrm{HCl}$. When this hydrolysed product was applied to paper chromatograms and developed with each of the four solvents previously mentioned it was observed that sucrose had disappeared and two products, which moved the same distance as glucose and fructose, had been formed. These substances gave the characteristic reactions of glucose and fructose when sprayed with benzidine and naphtharesorcinol. Fehling's solution was not reduced by the synthetic sucrose but was readily reduced by the hydrolysis products.

\section{DISCUSSION}

There is evidence (Turner, 1954) that a glycolytic system was operating during the formation of sucrose by digests containing the partially purified extract. As the enzyme digests showed no significant oxygen uptake it may be concluded that oxidative metabolism was not proceeding to a significant extent.

As sucrose synthesis is dependent on the presence of diphosphopyridine nucleotide and is stimulated by the addition of adenosine phosphates it may be assumed that the glycolytic system, and therefore probably phosphorylation, plays some part in the formation of the disaccharide. This may indicate 
that glucose 1-phosphate or fructose, or both these substances, are involved in a phosphorylation before the formation of sucrose.

Uridine derivatives may be involved in sucrose synthesis by pea extracts. The yeast-nucleotide fraction, which gave stimulation of sucrose formation with the partially purified extract, contained relatively large amounts of uridine compounds. Stimulation was also given by uridine monophosphate. These observations are consistent with the hypothesis of Buchanan et al. (1952), that UDPG may act as glucose donor in sucrose formation in plants. The operation of a glycolytic system during the synthesis of sucrose by the pea extracts would make possible the formation of uridine triphosphate (UTP) by phosphopyruvate kinase (Kornberg, 1951) or by the transphosphorylation from ATP (Berg \& Joklik, 1953) formed during glycolysis. There was insufficient preformed UDPG or ATP in the enzyme digests to account for the sucrose formed. UDPG may be formed from UTP and glucose 1-phosphate (Munch-Petersen, Kalckar, Cutolo \& Smith, 1953).

There is no evidence in the present work to support the hypothesis of Buchanan et al. (1952) that UDPG reacts with fructose 1-phosphate to give a sucrose phosphate. The addition of the free fructose to the enzyme digests was necessary for sucrose synthesis; there was no formation of sucrose when fructose was replaced by fructose 1-phosphate, fructose 6-phosphate or fructose 1:6-diphosphate (Turner, 1954). It is concluded that if UDPG is the precursor which denotes a glycosyl group for sucrose formation then the acceptor in the pea extracts is fructose and not a phosphoric ester of this sugar. This is in agreement with the results of Leloir \& Cardini (1953) and Cardini, Leloir \& Chiriboga (1955) who prepared enzymes from plants which formed sucrose from UDPG and fructose.

A number of reports have been published in which ${ }^{14} \mathrm{C}$-labelled sugars have been supplied as substrates to intact plant tissues and the labelling of the sucrose formed and the other free sugars present has been studied. Putman \& Hassid (1954) infiltrated disks from leaves of Canna indica with labelled sugars and concluded that free fructose was not an immediate precursor in sucrose formation. Vittorio, Krotkov \& Reed (1954) and Porter \& May (1955) used tobacco leaves and reached the same conclusion. Leloir \& Cardini (1955) have reported the presence in wheat germ of an enzyme which catalyses the reaction

$$
\begin{array}{r}
\text { UDPG + fructose 6-phosphate } \rightleftharpoons \\
\text { sucrose phosphate + UDP. }
\end{array}
$$

Phosphatase may then act on the sucrose phosphate so formed to yield free sucrose. This mechanism may also operate in leaves. However, as pointed out by
Edelman, Ginsburg \& Hassid (1955) and by Leloir \& Cardini (1955), the experiments with intact leaves do not eliminate the possibility that free fructose may be rapidly formed and utilized at the site of sucrose synthesis. It is worthy of note that Cardini et al. (1955) have found the enzyme catalysing the reaction between UDPG and fructose in a wide variety of plant tissues.

\section{SUMMARY}

1. An extract from pea seeds which formed sucrose from glucose 1-phosphate and fructose was partially purified by precipitation with ammonium sulphate and dialysis against phosphate buffer. The addition of a boiled crude pea extract was necessary to restore activity to the partially purified extract.

2. The boiled crude pea extract could be replaced by nucleotide fractions prepared from peas or yeast. Magnesium ions were essential for the synthesis.

3. The effects of concentration of $\mathrm{Mg}^{2+}$ ions, yeast-nucleotide fraction and substrates on sucrose synthesis were studied.

4. The nucleotide fractions could be replaced by a mixture of diphosphopyridine nucleotide, uridine monophosphate and adenosine triphosphate.

5. A sample of synthetic sucrose was prepared and some of its properties were studied.

6. The experimental evidence is consistent with the synthesis of sucrose by means of a reaction between uridine diphosphate glucose and fructose.

The author wishes to express his indebtedness to Dr L. W. Mapson, Professor C. S. Hanes, F.R.S. (who suggested the study of sucrose synthesis), Dr J. Barker, F.R.S., Professor G. E. Briggs, F.R.S., and Dr F. A. Isherwood for their advice and interest. Financial assistance was provided initially by the Australian Commonwealth Scientific and Industrial Research Organization, and the investigation was continued during the tenure of a Broodbank Fellowship of the University of Cambridge. Support from these sources is gratefully acknowledged.

\section{REFERENCES}

Allen, R. J. L. (1940). Biochem. J. 34, 858.

Bacon, J. S. D. \& Edelman, J. (1951). Biochem. J. 48, 114. Berg, P. \& Joklik, W. K. (1953). Nature, Lond., 172, 1008. Bryson, J. L. \& Mitchell, T. J. (1951). Nature, Lond., 167, 864.

Buchanan, J. G., Bassham, J. A., Benson, A. A., Bradley, D. F., Calvin, M., Daus, L. L., Goodman, M., Hayes, P. M., Lynch, V. H., Norris, L. T. \& Wilson, A. T. (1952). Phosphorus Metabolism, vol. 2, p. 440. Ed. by McElroy, W. D. \& Glass, B. Baltimore: Johns Hopkins Press.

Calvin, M. \& Benson, A. A. (1949). Science, 109, 140.

Caputto, R., Leloir, L. F., Cardini, C. E. \& Paladini, A. C. (1950). J. biol. Chem. 184, 333.

Cardini, C. E., Leloir, L. F. \& Chiriboga, J. (1955). J. biol. Chem. 214, 149. 
Cole, S. W., Hanes, C. S., Jackson, H. A. F. \& Loughman, B. C., quoted by Bell, D. J. (1955). In Modern Methods of Plant Analysis, vol. 2, p. 1. Ed. by Paech, K. \& Tracey, M. V. Berlin, Göttingen, Heidelberg: Springer-Verlag.

Edelman, J., Ginsburg, V. \& Hassid, W. Z. (1955). J. biol. Chem. 213, 843.

Euler, H. von, Schlenk, F., Heiwinkel, H. \& Högberg, B. (1938). Hoppe-Seyl. Z. 256, 208.

Kornberg, A. (1951). Phosphorus Metabolism, vol. 1, p. 392. Ed. by McElroy, W. D. \& Glass, B. Baltimore: Johns Hopkins Press.

Leloir, L. F. \& Cardini, C. E. (1953). J. Amer. chem. Soc. 75, 6084.

Leloir, L. F. \& Cardini, C. E. (1955). J. biol. Chem. 214, 157.
Leonard, O. A. (1939). Amer. J. Bot. 26, 475.

Munch-Petersen, A., Kalckar, H. M., Cutolo, E. \& Smith, E. E. B. (1953). Nature, Lond., 172, 1036.

Nelson, J. M. \& Auchincloss, R. (1933). J. Amer. chem. Soc. 55, 3769.

Nurmia, N. (1935). Ann. Acad. Sci.fenn. A, 44, no. 8.

Porter, H. K. \& May, L. H. (1955). J. exp. Bot. 6, 43.

Putman, E. W. \& Hassid, W. Z. (1954). J. biol. Chem. 207, 885.

Trevelyan, W. E., Procter, D. P. \& Harrison, J. S. (1950). Nature, Lond., 166, 444.

Turner, J. F. (1953). Nature, Lond., 172, 1149.

Turner, J. F. (1954). Nature, Lond., 174, 692.

Vittorio, P. V., Krotkov, G. \& Reed, G. B. (1954). Canad. J. Bot. 32, 369.

\title{
Formation of 3-Hydroxybutan-2-one and Butane-2:3-diol by Pig-heart Preparations and its Relationship to Oxidation of Pyruvate
}

\author{
BY J. DAWSON, R. P. HULLIN AND MARJORIE WALKER \\ Department of Biochemistry, University of Leeds
}

(Received 21 November 1956)

3-Hydroxybutan-2-one (acetoin) appears in mammalian systems, plants and yeasts to be formed by a similar mechanism. Pyruvate is decarboxylated to an active form of acetaldehyde, probably an acetaldehyde-diphosphothiamine complex, $\left[\mathrm{CH}_{3} \cdot \mathrm{CHO}\right]$, which condenses with free acetaldehyde:

$\mathrm{CH}_{3} \cdot \mathrm{CO} \cdot \mathrm{CO}_{2} \mathrm{H} \rightarrow \mathrm{CO}_{2}+\left[\mathrm{CH}_{3} \cdot \mathrm{CHO}\right]$

$\left[\mathrm{CH}_{3} \cdot \mathrm{CHO}\right]+\mathrm{CH}_{3} \cdot \mathrm{CHO} \rightarrow \mathrm{CH}_{3} \cdot \mathrm{CO} \cdot \mathrm{CH}(\mathrm{OH}) \cdot \mathrm{CH}_{3}$.

All the evidence suggests that only pyruvic oxidase is required for the condensation (Berg \& Westerfeld, 1944; Juni, 1952; Singer \& Pensky, 1952; Langenbeck \& Faust, 1953).

This mechanism differs from the one most commonly observed in bacteria, i.e. formation of a complex followed by condensation with pyruvate to form $\alpha$-acetyl-lactate, which is then decarboxylated to acetoin (Slade \& Werkman, 1943; Krampitz, 1948; Strecker \& Ochoa, 1954):

$$
\begin{aligned}
\mathrm{CH}_{3} \cdot \mathrm{CHO}+\mathrm{CH}_{3} \cdot \mathrm{CO} \cdot \mathrm{CO}_{2} \mathrm{H} \rightarrow \\
\quad \mathrm{CH}_{3} \cdot \mathrm{CO} \cdot \mathrm{C}(\mathrm{OH})\left(\mathrm{CO}_{2} \mathrm{H}\right) \cdot \mathrm{CH}_{3} \rightarrow \\
\mathrm{CH}_{3} \cdot \mathrm{CO} \cdot \mathrm{CH}(\mathrm{OH}) \cdot \mathrm{CH}_{3}+\mathrm{CO}_{2} .
\end{aligned}
$$

Decarboxylation of pyruvic acid is common to both systems and also to the system concerned with acetyl-coenzyme A (acetyl-CoA) formation. The main difference between the three systems is the acceptor for the activated acetaldehyde produced. In bacterial production of acetoin pyruvic acid is the acceptor, with the intermediate production of $\alpha$-acetyl-lactic acid; in plants, yeasts and mammals the acceptor is free acetaldehyde, and for formation of acetyl-CoA $\alpha$-lipoic acid acts as an intermediate acceptor (Schweet \& Cheslock, 1952; Stotz, 1954).
Formation of activated acetaldehyde from pyruvate probably occurs in the same manner in all organisms, though its further metabolism is influenced by the availability of other enzymes and cofactors. This was demonstrated by Stern, Shapiro, Stadtman \& Ochoa (1951) and by Korkes, del Campillo, Gunsalus \& Ochoa (1951), who showed that pyruvic oxidases from mammalian and bacterial sources were interchangeable. The former workers discovered that soluble enzyme preparations from Escherichia coli and Streptococcus faecalis in the presence of diphosphopyridine nucleotide (DPN) catalysed the reaction:

$$
\begin{aligned}
& 2 \text { Pyruvate + phosphate } \rightarrow \\
& \text { lactate + acetyl phosphate }+\mathrm{CO}_{2} \text {. }
\end{aligned}
$$

In the presence of bacterial phosphotransacetylase and coenzyme $A(\mathrm{CoA})$ the following reaction occurred:

$$
\begin{array}{r}
\text { Acetyl phosphate }+\mathrm{CoA} \rightarrow \\
\text { acetyl-CoA }+ \text { phosphate. }
\end{array}
$$

In the absence of phosphate these reactions could not occur, but, if phosphate and bacterial phosphotransacetylase were replaced by oxaloacetate and mammalian condensing enzyme, reaction occurred:

$$
2 \text { Pyruvate + oxaloacetate } \rightarrow \text { citrate }+\mathrm{CO}_{2} \text { + lactate. }
$$

Korkes et al. (1951) prepared an enzyme from pigheart muscle which, supplied with the appropriate cofactors, would synthesize citrate from pyruvate and oxaloacetate in the presence of condensing 